\title{
INCIDENCE AND HISTOMORPHOLOGICAL EVALUATION OF PAEDIATRIC NON-HAEMATOLOGICAL MALIGNANT TUMOURS IN A TERTIARY CARE HOSPITAL
}

\author{
Revathi Ramakrishnan1, Kavitha Duraisamy²
}

${ }^{1}$ Associate Professor, Department of Pathology, Government Theni Medical College, Theni.

${ }^{2}$ Associate Professor, Department of Pathology, Government Theni Medical College, Theni.

\begin{tabular}{l}
\hline ABSTRACT \\
\hline BACKGROUND \\
Paediatric cancers differ markedly from adult malignancies in their distribution by histology, tumour site, and in prognosis. \\
Molecular cytogenetic, immunohistochemistry, and histochemical stains play a major role in determining the exact underlying \\
pathology of various paediatric cancers.
\end{tabular}

\section{MATERIALS AND METHODS}

In this study, we had taken 69 cases of paediatric neoplasms with children presented with paediatric solid tumours and brain neoplasms. Cases with lymph node swelling and haematological malignancies were not included in this study.

\section{OBSERVATION AND RESULTS}

This study covered a total of 69 non-haematological paediatric cancers in which 48 were paediatric solid tumours and 21 were CNS neoplasms. Paediatric solid tumours were common in male children than in female children and there was increased incidence in the age group of 3-4 yrs. when the paediatric solid tumours were categorised. Neuroblastoma with incidence of $16.67 \%$ (8 cases) predominates over other malignancies followed by ovarian tumours and extra skeletal Ewing sarcoma ( 5 cases, $10.42 \%$ ). In $21 \mathrm{CNS}$ tumours observed in this study, 12 cancers were seen in male children (57.14\%) and 9 were females (42.86\%). Male predominant was noted in CNS neoplasm also and there was increased incidence of cancers during 9-10 yrs. when CNS neoplasms were categorised. Medulloblastoma/PNET predominates with [8 cases (38.09\%)], in the age group of 4-11 yrs. followed by astrocytomas, [7cases $(33.33 \%)]$.

\section{CONCLUSION}

In our study, neuroblastoma being the most common abdominal soft-tissue neoplasms. Ewing sarcoma and ovarian neoplasms constitute second most common non-CNS neoplasms. Hepatoblastoma, retinoblastoma, and colorectal adenocarcinomas each constitutes about $8.33 \%$ of cases. Embryonal rhabdomyosarcomas was observed in next order frequency and osteosarcoma constitutes about $6.25 \%$ of cases. Wilms' tumour was the common form of renal cancer in children. Paediatric CNS neoplasm constitutes about $15.90 \%$ with peak age at presentation during 9-10 years and more than $10 \mathrm{yrs}$. The incidence is also slightly higher in males with M:F of 1.3:1. Medulloblastoma is the commonest childhood neoplasm. Astrocytomas constitute about 33.33\% of cases in which 3 cases goes difficulty on diagnosis at light microscopy level. Immunohistochemical marker, GFAP, EMA, and vimentin will help in arriving final diagnosis.

\section{KEYWORDS}

Paediatric, CNS Tumours, Incidence.

HOW TO CITE THIS ARTICLE: Ramakrishnan R, Duraisamy K. Incidence and histomorphological evaluation of paediatric nonhaematological malignant tumours in a tertiary care hospital. J. Evolution Med. Dent. Sci. 2016;5(60):4165-4170, DOI: $10.14260 /$ jemds/2016/951

\section{INTRODUCTION}

Paediatric cancers differ markedly from adult malignancies in their distribution by histology, tumour site, and in prognosis. Unlike incidence pattern in adults where cancer rates tend to rapidly increase with increasing age, 1 relatively wide age variability exists during development with two peaks in early childhood and in adolescence.

It appears that adolescence is a transitional period between the common early childhood malignancies and characteristic carcinomas of adulthood. The mortality rate of

Financial or Other, Competing Interest: None.

Submission 01-07-2016, Peer Review 16-07-2016,

Acceptance 19-07-2016, Published 26-07-2016.

Corresponding Author:

Dr. Revathi Ramakrishnan,

\#1-1-93/F10, Usilai Road,

Peraiyur, Madurai-625703,

Tamilnadu.

E-mail: revathiram67@gmail.com

DOI: $10.14260 /$ jemds/2016/951 cancer in children is approximately 3 to 5 deaths/1 lakh population/year.

In general, there is diversity in the occurrence of paediatric neoplasm all over the world. In this study, the actual incidence and presentation of paediatric neoplasm in semi urban area is evaluated with keen attention to clinical features, role of environmental $^{2}$ factors, and consanguinity, and initial cytomorphological evaluation with fine needle aspiration for a proportion of cases. As paediatric neoplasms are often anaplastic cancers, they pose a challenge to surgical pathologists. Paediatric oncology faces unique challenges because treatment with radiation surgery and chemotherapy may adversely affect growth and development and may cause serious long-term medical and psychosocial effect.

Molecular cytogenetics, immunohistochemistry, and histochemical stains play a major role in determining the exact underlying pathology of various paediatric cancers.

This study is undertaken in view of evaluating the actual incidence of paediatric neoplasms in semi-urban area with particular attention to the age, sex, site, and histopathology of 
cancers and also to study the value of immunohistochemistry in final diagnosis of paediatric tumours. In addition, the recent literatures, journals, and research publications regarding paediatric cancers are also immensely reviewed.

\section{MATERIALS AND METHODS}

Children and adolescents presented with malignant neoplasms referred during 2003-2005 were included in this study. A thorough clinical evaluation, routine haematological investigations, ultrasonogram, and CT scan (In proportion of cases) were done in each case. A detailed history with particular attention to consanguinity, socioeconomic status, nutrition and radiation, exposure to pesticides, parental occupation, and also similar neoplasms in other family members were also recorded.

The paediatric solid tumours and brain neoplasms were examined carefully from the reception itself. Larger specimens were sliced at $1 \mathrm{~cm}$ interval without distorting the gross pathology fixed in neutral buffered formalin and processed routinely. 3 to 5 micron sections were cut and stain with routine $\mathrm{H}$. and E. immunohistochemistry with GFAP marker were also performed in doubtful CNS neoplasms.

\section{OBSERVATION AND RESULTS}

This study covered a total of 69 non-haematological paediatric cancers in which 48 were paediatric solid tumours and 21 were CNS Neoplasms.

\section{Paediatric Solid Tumours}

In this study, 48 paediatric solid tumours were observed in which 25 were male children $(52.08 \%)$ with age ranging from 1 month to 15 yrs. (Mean age-7.04 yrs.), 23 were female $(47.92 \%)$ with age ranging from 1 month to $15 \mathrm{yrs}$. (Mean age7.08 yrs.).

The following Table No. 1 shows the total number of paediatric solid tumours observed during the period from January 2003 to December 2005. The average incidence is $36.36 \%$.

In Table-2, there was increased incidence of paediatric solid tumours in the age group of 3-4 yrs. followed by more than 10 yrs. and less than 2 yrs.

The Table- 2 also shows that the incidence of paediatric solid tumours common in males [25 cases (52.08\%)] when compared with females [23 cases (47.92\%)].

When the paediatric solid tumours ${ }^{3,4}$ are categorised as given in the following Table-3, neuroblastoma with incidence of $16.67 \%$ (8 cases) predominates over other malignancies followed by ovarian tumours and extra skeletal Ewing sarcoma ( 5 cases, $10.42 \%$ ).

In this study, 4 cases of hepatoblastoma, 4 cases of colorectal adenocarcinoma, and 4 cases of retinoblastoma were also observed. Osteosarcoma, rhabdomyosarcoma, nasopharyngeal and laryngeal neoplasms were observed only in 3 cases respectively.

Likewise, Wilms' tumour.5,6 once thought to be a common paediatric neoplasm was observed in only one case.

Table- 3 also shows one interesting case of melanoma, which is observed at 3 yrs. male child in the intraoral region, testicular tumour is observed at 3 yrs., and adrenocortical neoplasm at the age of 4 yrs.

\section{CNS Neoplasms}

In 21 CNS tumours observed in this study, 12 cancers were seen in male children (57.14\%) with age ranging from 1-15 yrs. (Mean age 8.33 yrs.) and 9 were females (42.86\%) with age ranging from 1-15 yrs. (Mean age $8.77 \mathrm{yrs}$.).

The average incidence of paediatric CNS neoplasm is $15.90 \%$ as given in the following Table No 4 during the period from January 2003 to December 2005.

When the children with CNS Neoplasms were also divided into 6 groups as done in the paediatric solid neoplasms, there was increased incidence of cancers during 9-10 yrs. and more than 10 yrs. (7 cases $33.33 \%$ ) followed by $2-3$ yrs. and less than 2 yrs. ( 3 cases $14.29 \%$ ).

Incidence is common in males (12 cases, $57.14 \%$ ) as in paediatric solid neoplasms when compared with females (9 cases $42.86 \%$ ).

The Table No 6 shows paediatric CNS neoplasm distribution.7,8 Medulloblastoma/PNET predominates with [8 cases $(38.09 \%)]$ in the age group of $4-11$ yrs. followed by astrocytomas [7 cases (33.33\%)], and ependymomas [3 cases (14.29\%)]. 2 cases of pineoblastoma/pineocytoma and one case of chordoma at the age of 9-15 yrs. and 3 yrs. were also observed.

\section{Immunohistochemistry}

Immunohistochemical stains GFAP-for astrocytoma was undertaken and the results were given in the following Table 5.

\begin{tabular}{|c|c|c|c|c|}
\hline $\begin{array}{c}\text { Sl. } \\
\text { No. }\end{array}$ & Period & $\begin{array}{c}\text { Total No. } \\
\text { of Non-CNS } \\
\text { Malignancy }\end{array}$ & $\begin{array}{c}\text { Paediatric } \\
\text { Cases }\end{array}$ & Percentage \\
\hline 1. & $\begin{array}{c}\text { Jan. 2003- } \\
\text { Dec. 2003 }\end{array}$ & 132 & 12 & $9.1 \%$ \\
\hline 2. & $\begin{array}{l}\text { Jan. 2004- } \\
\text { Dec. 2004 }\end{array}$ & 198 & 14 & $7.1 \%$ \\
\hline 3. & $\begin{array}{l}\text { Jan. 2005- } \\
\text { Dec. 2005 }\end{array}$ & 282 & 22 & $7.8 \%$ \\
\hline \multicolumn{5}{|c|}{$\begin{array}{c}\text { Table 1: Shows Total Number of Paediatric } \\
\text { Solid Tumours During 2003-2005 }\end{array}$} \\
\hline
\end{tabular}

\begin{tabular}{|c|c|c|c|c|c|}
\hline $\begin{array}{c}\text { Sl. } \\
\text { No. }\end{array}$ & Age & Male & Female & $\begin{array}{c}\text { Total No. } \\
\text { of Cases }\end{array}$ & Percentage \\
\hline 1 & $<=2$ & 4 & 4 & 8 & $16.67 \%$ \\
\hline 2 & $3-4$ & 11 & 5 & 16 & $33.33 \%$ \\
\hline 3 & $5-6$ & - & 4 & 4 & $8.33 \%$ \\
\hline 4 & $7-8$ & - & 2 & 2 & $4.17 \%$ \\
\hline 5 & $9-10$ & 4 & - & 4 & $8.33 \%$ \\
\hline 6 & $>10$ & 6 & 8 & 14 & $29.17 \%$ \\
\hline \multicolumn{6}{|c|}{ Table 2: Shows Age and Sex Distribution } \\
of Paediatric Solid Tumours \\
\hline
\end{tabular}

\begin{tabular}{|c|c|c|c|}
\hline $\begin{array}{c}\text { Sl. } \\
\text { No }\end{array}$ & $\begin{array}{c}\text { Solid } \\
\text { Tumours }\end{array}$ & $\begin{array}{c}\text { No. of } \\
\text { Case }\end{array}$ & Percentage \\
\hline 1 & Malignant Melanoma & 1 & $2.08 \%$ \\
\hline 2 & $\begin{array}{c}\text { Colorectal Malignant } \\
\text { Neoplasm }\end{array}$ & 4 & $8.33 \%$ \\
\hline 3 & $\begin{array}{c}\text { Nasopharyngeal } \\
\text { and Laryngeal Neoplasm }\end{array}$ & 3 & $6.25 \%$ \\
\hline 4 & Ovarian Tumour & 5 & $10.42 \%$ \\
\hline 5 & Testicular Tumour & 1 & $2.08 \%$ \\
\hline
\end{tabular}




\begin{tabular}{|c|c|c|c|}
\hline 6 & $\begin{array}{l}\text { Adrenal Cortical } \\
\text { Neoplasm }\end{array}$ & 1 & $2.08 \%$ \\
\hline 7 & Retinoblastoma & 4 & $8.33 \%$ \\
\hline 8 & Neuroblastoma & 8 & $16.67 \%$ \\
\hline 9 & Hepatoblastoma & 4 & $8.33 \%$ \\
\hline 10 & $\begin{array}{l}\text { Extra Skeletal Ewing } \\
\text { Sarcoma }\end{array}$ & 5 & $10.42 \%$ \\
\hline 11 & Rhabdomyosarcoma & 2 & $6.25 \%$ \\
\hline 12 & Low-Grade MPNST & 2 & $4.17 \%$ \\
\hline 13 & $\begin{array}{l}\text { Bone Tumour - } \\
\text { Osteosarcoma }\end{array}$ & 3 & $6.25 \%$ \\
\hline 14 & Wilms' Tumour & 1 & $2.08 \%$ \\
\hline 15 & Salivary Gland Tumour & 1 & $2.08 \%$ \\
\hline 16 & Others & 2 & $4.17 \%$ \\
\hline \multicolumn{4}{|c|}{$\begin{array}{c}\text { Table 3: Shows Categorisation of } \\
\text { Paediatric Solid Tumours }\end{array}$} \\
\hline
\end{tabular}

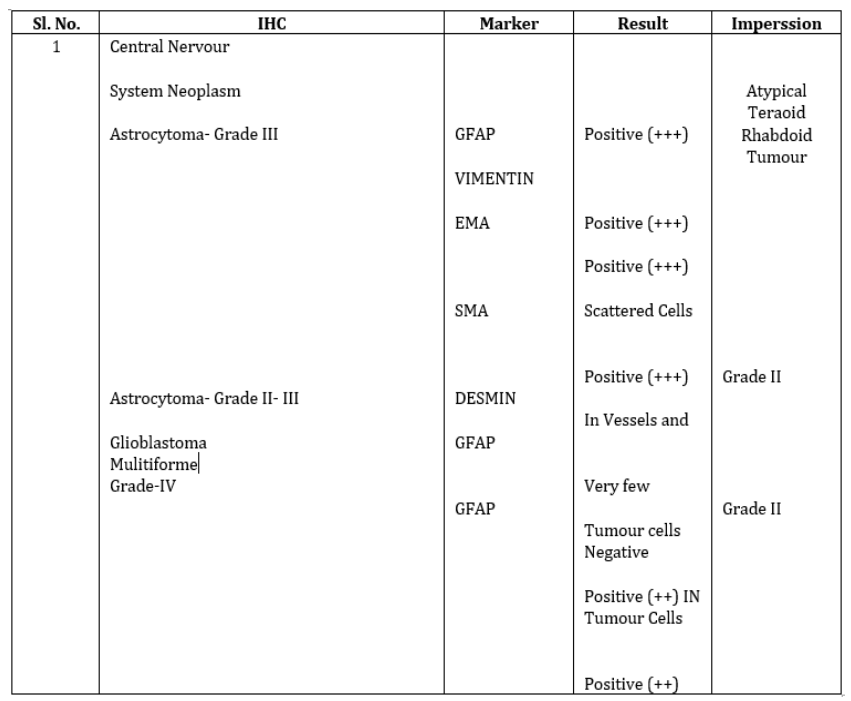

Table 7: Shows Immunohistochemical Stain Results and Interpretations

\begin{tabular}{|c|c|c|c|c|}
\hline $\begin{array}{c}\text { Sl. } \\
\text { No. }\end{array}$ & Period & $\begin{array}{c}\text { Total } \\
\text { No. of } \\
\text { Neoplasms }\end{array}$ & $\begin{array}{c}\text { Paediatric } \\
\text { Cancers }\end{array}$ & Percentage \\
\hline 1 & $\begin{array}{c}\text { Jan. 2003- } \\
\text { Dec. 2003 }\end{array}$ & 18 & 5 & $27.78 \%$ \\
\hline 2 & $\begin{array}{c}\text { Jan. 2004- } \\
\text { Dec. 2004 }\end{array}$ & 21 & 5 & $23.80 \%$ \\
\hline 3 & $\begin{array}{c}\text { Jan. 2005- } \\
\text { Dec. 2005 }\end{array}$ & 32 & 11 & $34.37 \%$ \\
\hline \multicolumn{5}{|c|}{ Table 4: Total Number of Paediatric } \\
CNS Neoplasms During 2003-2005 \\
\hline
\end{tabular}

\begin{tabular}{|c|c|c|c|c|c|}
\hline $\begin{array}{c}\text { Sl. } \\
\text { No. }\end{array}$ & Age & Male & Female & $\begin{array}{c}\text { Total No. } \\
\text { of Cases }\end{array}$ & Percent \\
\hline 1 & $<2$ & 1 & 2 & 3 & $14.29 \%$ \\
\hline 2 & $3-4$ & 3 & - & 3 & $14.29 \%$ \\
\hline 3 & $5-6$ & 1 & - & 1 & $4.76 \%$ \\
\hline 4 & $7-8$ & - & - & - & - \\
\hline 5 & $9-10$ & 3 & 4 & 7 & $33.33 \%$ \\
\hline 6 & $>10$ & 4 & 3 & 7 & $33.33 \%$ \\
\hline \multicolumn{6}{|c|}{ Table 5: Age and Sex Incidence of } \\
Paediatric CNS Neoplasms \\
\hline
\end{tabular}

\begin{tabular}{|c|c|c|c|}
\hline $\begin{array}{c}\text { Sl. } \\
\text { No. }\end{array}$ & CNS Tumours & $\begin{array}{c}\text { No. of } \\
\text { Cases }\end{array}$ & Percentage \\
\hline 1 & Medulloblastoma/PNET & 8 & $38.09 \%$ \\
\hline 2 & Ependymoma & 3 & $14.29 \%$ \\
\hline 3 & Astrocytoma & 7 & $33.33 \%$ \\
\hline 4 & Chordoma & 1 & $4.76 \%$ \\
\hline 5 & Pineoblastoma/Pineocytoma & 2 & $9.52 \%$ \\
\hline \multicolumn{3}{|c|}{ Table 6: Categorisation of Paediatric CNS Tumours } \\
\hline
\end{tabular}

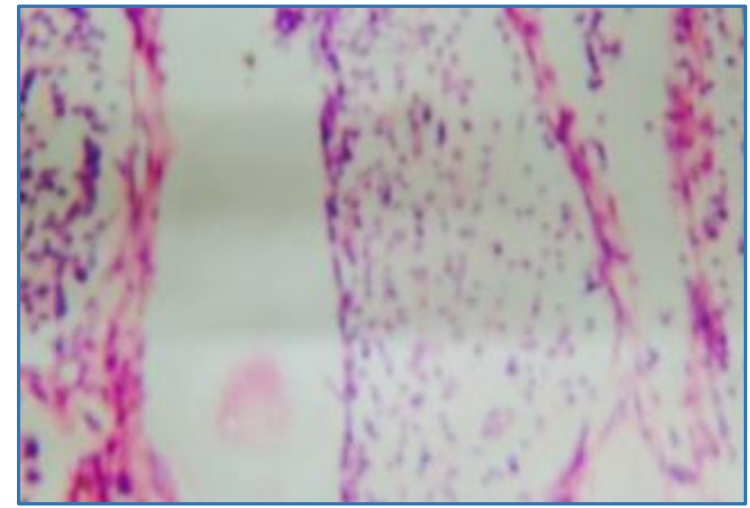

Fig. 1: Neuroblastoma-High Power View Shows the Fine Eosinophilic Network in Between the Tumour Cell Nuclei (Neuropil)

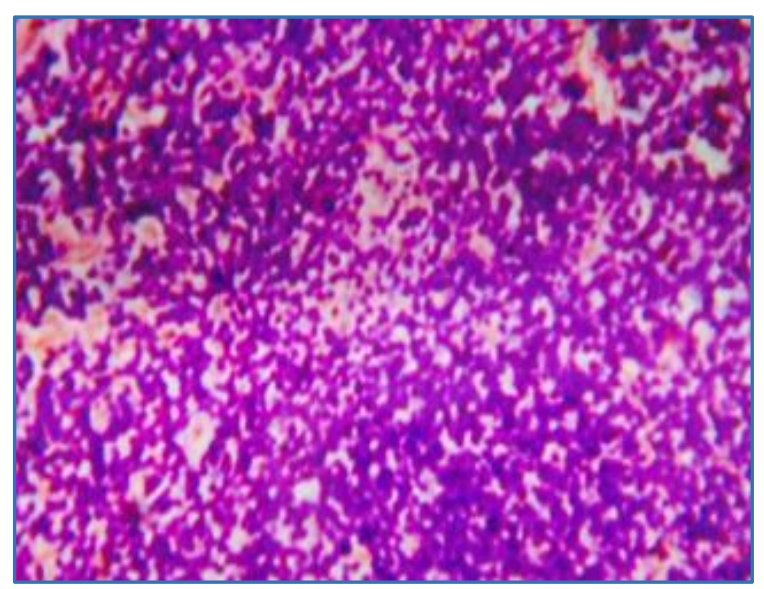

Fig. 2: Extra Skeletal Ewing's Sarcoma/PNETTumour Cells Seen Around the Blood Vessels 


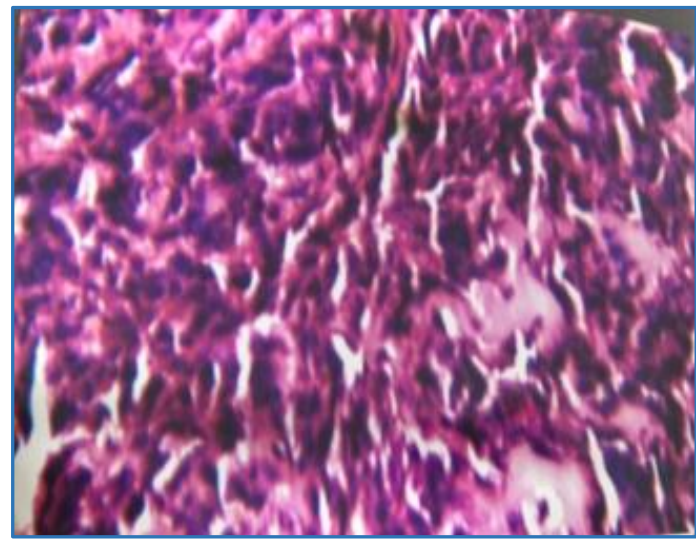

Fig. 3: Osteosarcoma-High Power View Shows Osteoid with Tumour

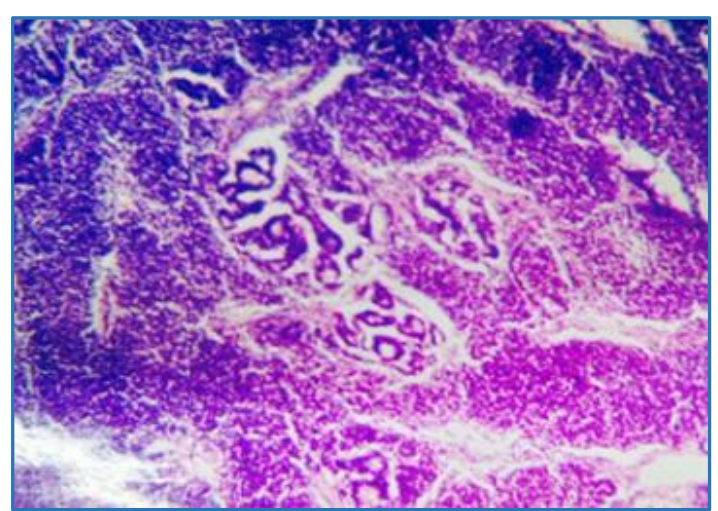

Fig. 4: Wilms' Tumour-Blastemal, Stromal, and Epithelial Tubular Formation

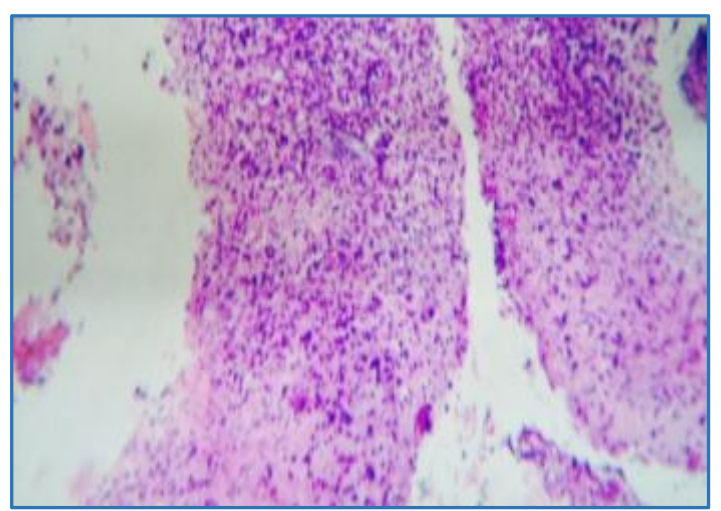

Fig. 5: Atypical Rhabdoid Teratoid Tumour: Scan Power View Shows Increased Cellularity and Microvascular Proliferations

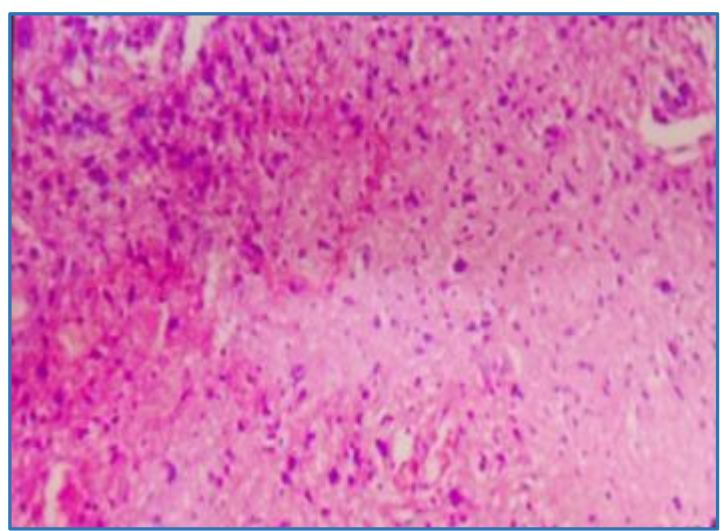

Fig. 6: Atypical Rhabdoid Teratoid Tumour: Low Power View Shows the Bizarre Nature of the Tumour Cells

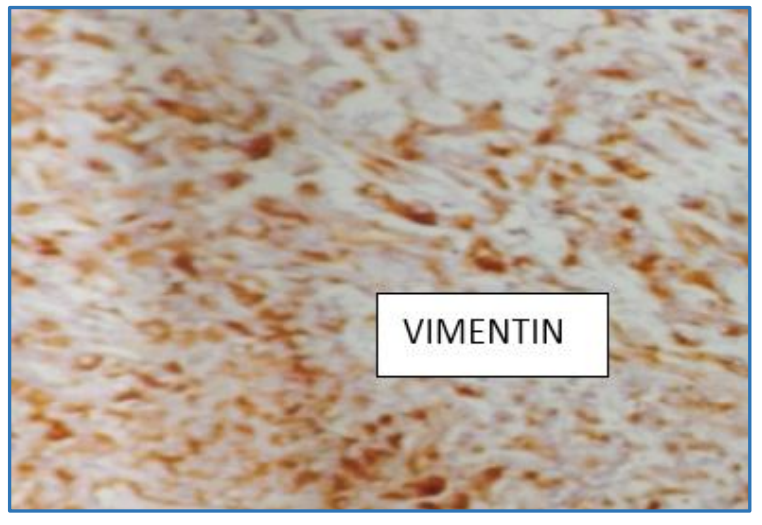

Fig. 7: Atypical Rhabdoid Teratoid Tumour-Vimentin Positive

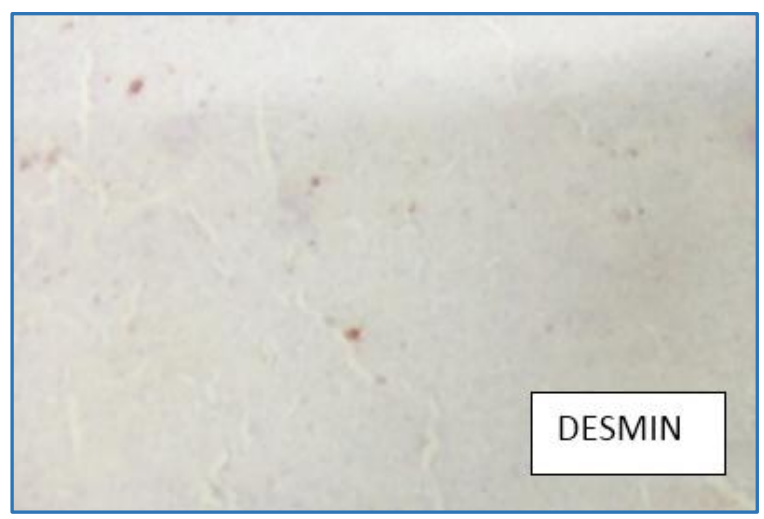

Fig. 8: Atypical Rhabdoid Teratoid TumourDesmin Negative in Tumour Cells

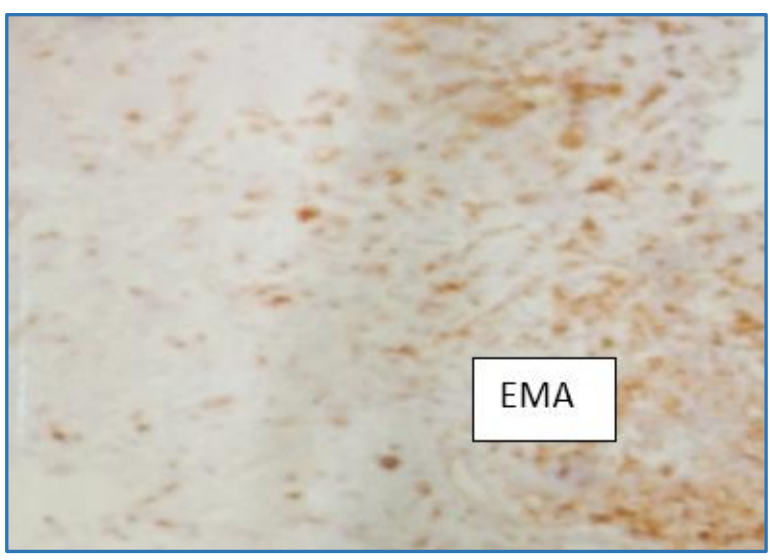

Fig. 9: Atypical Rhabdoid Teratoid TumourEMA Positive in Scattered Cells

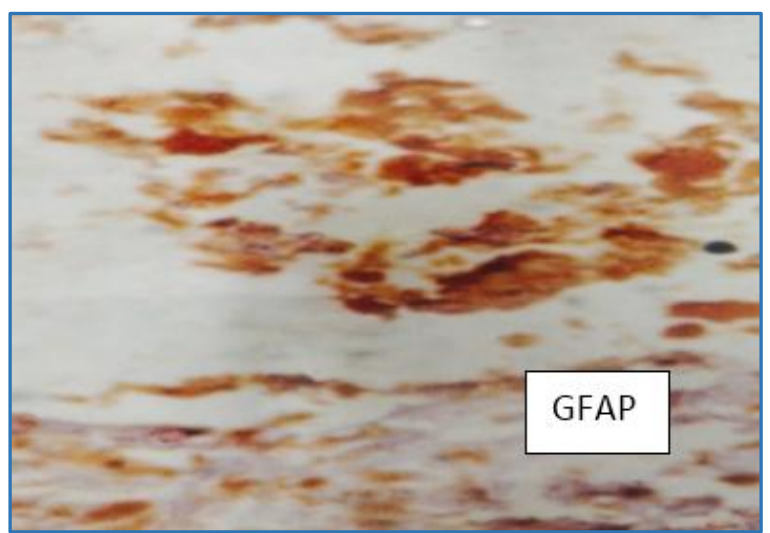

Fig. 10: Atypical Rhabdoid Teratoid Tumour-GFAP Positive in Tumour Cells 


\section{DISCUSSION}

Although, cancer among children is relatively uncommon. It remains a significant cause of mortality in this population and is second only to accidents as a cause of death in the age group of 5-14 years.

Neuroblastoma (Fig. 1) being the most common abdominal paediatric solid tumours. ${ }^{8,9}$ observed in our study as other researches Ewing sarcoma (Fig. 2) and ovarian neoplasms constitute second most common non-CNS tumours.

In this study, hepatoblastoma. ${ }^{10}$ retinoblastoma, and colorectal adenocarcinomas each constitutes about $8.33 \%$ of cases. Hepatic tumours account for approximately $1 \%$ of child malignancies with hepatoblastoma (HB) and hepatocellular carcinoma (HCC) constituting the majority. Because of their rarity generalizations regarding the epidemiology are difficult. Worldwide HB occurs almost twice as often as HCC in children.

Male predominance has been pointed out in the report of Chen et al and our study disclosed a similar result.

Routine newborn screening by paediatrician with physical exam is the only way to find the abdominal mass. But, it is always too late for high stages. In the paediatric literature, several cases have been diagnosed postnatally within 6 weeks after delivery suggesting that HB may arise during foetal life. But, only one case report could be found about antenatal diagnosis of congenital HB in uterus as initial presentation of enlarged foetal abdominal circumference at 36 weeks of gestation. Now, the prenatal sonogram is prevalent and may help in an early diagnosis of liver tumours.

Retinoblastoma is the most common intraocular tumour in childhood 11,12 and the most common tumour of the retina, but it is a rare malignant tumour with a prevalence of about $1 / 23,000$ live births.

Rhabdomyosarcoma. ${ }^{13,14,15}$ are malignant neoplasm, which show morphologic, immunohistochemical, and ultrastructural or molecular genetic evidence of primary skeletal muscle differentiation usually in the absence of any other pattern of differentiation.

Soft tissue sarcoma occur with an annual incidence of 8.4 cases/million white children younger than 15 years of age incidence in black children is $50 \%$ of that white children. ${ }^{9}$

Malignancies of the kidney (Renal cancers) represented $6.3 \%$ of cancer diagnosis among children younger than $15 \mathrm{yrs}$. of age (Incidence 7.9 per million) and $4.4 \%$ of cancer diagnosis for children and adolescents younger than 20 years of age (Incidence of 6.2 per million).

Wilms' tumour was by far the most common form of renal cancer in children. The highest incidence of Wilms' tumour occurred most commonly among children younger than 5 years of age with very low incidence for 10-14 and 15-19 year olds. The highest incidence for Wilms' tumour was in the first 2 years of life followed by steadily decreasing rates with increasing age.

In our study, osteosarcoma constitutes about $6.25 \%$ of cases. Osteosarcoma can be defined simply as a malignant tumour in which osteoid or bony matrix is produced by the tumour cells. (Fig. 3). In our malignant mixed germ cell tumours and gonadoblastoma constitute about $10.42 \%$ of cases.

In our study, paediatric CNS neoplasm constitutes about $15.90 \%$ with peak age at presentation during 9-10 years and more than 10 years. These figures are in contrast with nonCNS tumours in which most of the cases are seen in $<5 \mathrm{yrs}$. of age. The incidence is also slightly higher in males, with M:F of 1.3:1.

In our study, medulloblastoma ${ }^{16.17}$ is the commonest childhood neoplasm, which is in correlation with the data provided by the National Cancer Institute as well as the study conducted by the various research workers and authors.7,10

\section{TWO MAJOR RISK GROUP CATEGORIES DEFINED BY CLINICAL CRITERIA ARE NOW BEING USED Average Risk}

Children older than 3 years with posterior fossa tumours; tumour is totally or near-totally ( $<1.5 \mathrm{cc}$ 's of residual disease) resected; no dissemination.

\section{Poor Risk}

Children 3 years old or younger or those with metastatic disease and/or subtotal resection (>1.5 cc's of residual disease) and/or non-posterior fossa location.

Astrocytomas. ${ }^{18,19}$ constitute about $33.33 \%$ of cases in which 3 cases goes difficulty on diagnosis at light microscopy level. With immunohistochemical marker, GFAP, 2 cases of grade-II anaplastic astrocytoma yielded positive result where as one case of anaplastic astrocytoma showed positivity for EMA and vimentin in association to GFAP and final impression of atypical teratoid rhabdoid tumour was made (Fig. 7,8,9,10).

Pineoblastoma/pineocytoma constitutes about $9.52 \%$ of cases, second most common tumour in the pineal region. Pineal parenchymal tumours arises from pinocytes. Pineoblastoma occurs predominately in childhood. Pineoblastoma is the most malignant variant and is considered a subgroup of PNETS of childhood.

\section{CONCLUSION}

In general, because of early detection and progress with therapeutic methods mortality rate due to malignancies as a whole during childhood has been decreasing. Although, mortality of children due to cancer fell in recent years. The incidence of childhood brain tumours is increasing.

In the present study of 69 cases of paediatric cancers evaluated with clinical light microscopy and IHC following conclusions are made and presented.

1. The average incidence of paediatric malignant neoplasm is $2 \%$.

2. The incidence of paediatric neoplasms are increasing trends with new modalities of investigating procedures.

3. No classical epidemiological or socioeconomic cause is identified as an aetiological features in paediatric cancers.

4. Paediatric cancers are common in male children with male to female ratio of 1.5:1.

5. The peak age of paediatric neoplasm is less than $5 \mathrm{yrs}$. of age.

6. Neuroblastoma is the most common paediatric solid neoplasm.

7. Rare tumours like colorectal adenocarcinoma, melanoma, and nasopharyngeal carcinoma are also occur even in paediatric age groups.

8. Primary CNS neoplasms are relatively rare in children in contrast with western population where brain tumours are common.

9. In case of doubtful histogenesis, immunohistochemistry is very useful for final diagnosis. 


\section{REFERENCES}

1. Ward E, DeSantis C, Robbins A, et al. Childhood and adolescent cancer statistics, 2014. CA A Cancer Journal for Clinicians 2014;64(2):83-103.

2. Scott $\mathrm{CH}$. Childhood cancer epidemiology in low-income countries. Cancer 2007;112(3):461-72.

3. Crist WM, Kun LE. Common solid tumours of childhood. N Engl J Med 1991;324:461-71.

4. Blair V, Birch JM. Patterns and temporal trends in the incidence of malignant disease in children: II. Solid tumours of childhood. European Journal of Cancer 1994;30(10):1498-511.

5. Hartley, Daubenton JD, Desai F. Bilateral Wilms' tumours: a single centre experience with 19 cases. Journal of Paediatric Surgery 2005;40(8):1289-94.

6. Ehrlich PF, Ritchey ML, Hauilton TE, et al. Quality assessment for Wilms' tumour: a report from the national Wilms' tumour study-5. Journal of Paediatric Surgery 2005;40(1):208-12.

7. Smith MA, Borisfredlin, Rie LAG, et al. Trends in reported evidence of primary malignant brain tumours in children in the United States. Journal of the National Cancer Institute 1998;90(17):1269-77.

8. Kiess, Wieland. Journal of Paediatric Endocrinology and Metabolism. DE Gruyter 2011;5:669-74.

9. Heck JE, Ritz B, Hung RJ, et al. The epidemiology of neuroblastoma: a review. Paediatric and Perinatal Epidemiology 2009;23(2):125-43.

10. Fuchs J, Rydzynski J, Schweinitz VD, et al. Pretreatment prognostic factors and treatment results in children with hepatoblastoma: a report from the German co-operative paediatric liver tumour study HB 94. Cancer 2002; 95(1):172-82.
11. Kumar V, Abbas AK, Fausto N. Robbins and Cotran pathologic basis of disease. $7^{\text {th }}$ ed. Philadelphia: Elsevier Saunders 2005:1442.

12. Schuler A, Weber S, Neuhauser M, et al. Age at diagnosis of isolated unilateral retinoblastoma does not distinguish patients with and without a constitutional RB1 gene mutation but is influenced by a parent-of-origin effect. Eur J Cancer 2005;41(5):735-40.

13. Qualman SJ, Coffin CM, Newton WA, et al. Intergroup rhabdomyosarcoma study: update for pathologist. Paediatr Dev Pathol 1998;1(6):550-61.

14. Hiniker SM, Donaldson SS. Recent advances in understanding and managing rhabdomyosarcoma. F1000prime Rep 2015;7:59.

15. Ognjanovic S, Linabery AM, Charbonneau B, et al. Trends in childhood rhabdomyosarcoma incidence and survival in the United States, 1975-2005. Cancer 2009;115(18): 4218-26.

16. Nicolas SR. Relative survival of childhood and adult medulloblastomas and primitive neuroectodermal tumours (PNETs). Cancer2012;118(5):1313-22.

17. Chris $H$, Deneen $H$. Focusing on brain tumours: medulloblastoma. American Brain Tumour Association. ISBN 0-944093-67-1.

18. Bailey P, Cushing HA. A classification of the tumours of the glioma group on a histogenetic basis with a correlated study of prognosis. British Journal of Surgery 1927; 14(55):554-5.

19. Batzdorf U, Gold V. Dispersion of central nervous system tumours. Correlation between clinical aspects and tissue culture studies. J Neurosurg 1974;41(6):691-8. 